\title{
Immunomodulatory role of Emblica officinalis in arsenic induced oxidative damage and apoptosis in thymocytes of mice
}

\author{
Manish K Singh, Suraj S Yadav, Vineeta Gupta and Sanjay Khattri
}

\begin{abstract}
Background: Arsenic is widely distributed in the environment and has been found to be associated with the various health related problems including skin lesions, cancer, cardiovascular and immunological disorders. The fruit extract of Emblica officinalis (amla) has been shown to have anti-oxidative and immunomodulatory properties. In view of increasing health risk of arsenic, the present study has been carried out to investigate the protective effect of amla against arsenic induced oxidative stress and apoptosis in thymocytes of mice.

Methods: Mice were exposed to arsenic (sodium arsenite $3 \mathrm{mg} / \mathrm{kg}$ body weight p.o.) or amla $(500 \mathrm{mg} / \mathrm{kg}$ body weight p.o.) or simultaneously with arsenic and amla for 28 days. The antioxidant enzyme assays were carried out using spectrophotometer and generation of ROS, apoptotic parameters, change in cell cycle were carried out using flow cytometer following the standard protocols.

Results: Arsenic exposure to mice caused a significant increase in the lipid peroxidation, ROS production and decreased cell viability, levels of reduced glutathione, the activity of superoxide dismutase, catalase, cytochrome c oxidase and mitochondrial membrane potential in the thymus as compared to controls. Increased activity of caspase-3 linked with apoptosis assessed by the cell cycle analysis and annexin V/PI binding was also observed in mice exposed to arsenic as compared to controls. Co-treatment with arsenic and amla decreased the levels of lipid peroxidation, ROS production, activity of caspase-3, apoptosis and increased cell viability, levels of antioxidant enzymes, cytochrome c oxidase and mitochondrial membrane potential as compared to mice treated with arsenic alone.
\end{abstract}

Conclusions: The results of the present study exhibits that arsenic induced oxidative stress and apoptosis significantly protected by co-treatment with amla that could be due to its strong antioxidant potential.

Keywords: Arsenic, Emblica officinalis, Oxidative stress, Apoptosis, Thymocytes

\section{Background}

Arsenic is considered as an environmental contaminant and widely distributed in the environment due to its natural existence and anthropogenic applications [1,2]. It has long been used in pharmaceuticals, glass industries, manufacturing of sheep-dips, leather preservatives, poisonous baits, pesticides and semiconductor devices [3-5]. Exposure to arsenic in human could occur through air, soil and other occupational sources [6]. Human exposure to arsenic through contaminated food materials is quite common

\footnotetext{
* Correspondence: drskhattri01@gmail.com

Department of Pharmacology, King George Medical University, Lucknow, Chowk 226 003, India
}

in the area having high levels of arsenic in ground water [6-8]. High levels of arsenic in ground water in India and many other regions of the world have been found to be associated with various health related problems including arsenicosis, skin lesions, cardiovascular diseases, reproductive problems, psychological, neurological and immunotoxic responses [2,9]. In view of increasing risk of arsenic toxicity, World Health Organization lowered the limit of arsenic in ground water from $50 \mu \mathrm{g} / \mathrm{l}$ to $10 \mu \mathrm{g} / \mathrm{l}$ [6].

Epidemiological studies have suggested that exposure to arsenic in humans may attributed to various immune related disorders [10-13]. In utero exposure to arsenic has been shown to suppress the immune mediated cells 
and impaired child thymic development associated with increased morbidity in children [14]. Exposure to arsenic during pregnancy has been found to lower thymic index suggested poor development of thymus in infants [15]. Increased placental inflammatory response, reduced placental $\mathrm{T}$ cells and altered levels of cord blood cytokines linked with fetal death, impaired infant health associated with enhanced oxidative stress have also been reported following exposure to arsenic [16,17]. Andrew et al. [10] observed that arsenic exposure may stimulate the over expression of genes involved in the defense system, immune function, cell growth, apoptosis, regulation of cell cycle, $\mathrm{T}$ cell receptor signaling pathway and diabetes. Association of arsenic intoxication with cancer, black foot disease and diabetes has also been reported [18,19]. Arsenic exposure in mice has been found to be associated with the increased free radical generation that affects the primary electron rich sites within the cells and cause DNA damage in human lymphocytes [20-22], breaking of DNA strand, DNA base modifications, protein crosslink, structural carbohydrates and lipids [23-25]. Arsenic induced cell death has been strongly linked to the induction of autophagy in human lymphoblastoid cell lines to impart its immunotoxic effects $[11,12]$. Numerous studies have reported that exposure to inorganic arsenic increased the frequency of micronuclei, chromosome aberrations and sister chromatid exchanges both in humans and experimental animals [26,27].

Recently, plant derived natural compounds and their active constituents have received great attention as a potential antioxidant against arsenic induced toxicity [21,28,29]. The fruit extract of Emblica officinalis (amla) with a history of medicinal value, long been used in Chinese and Indian traditional system of medicine and has shown antioxidative and immunomodulatory properties [30-33]. Amla contains a wide variety of phenolics including anthocyanins, flavonols, ellagic acid and its derivatives which protects against the harmful action of ROS and exhibits a wide range of biological effects including antioxidant, anti-tumour, anti-inflammatory, anti-bacterial and hepato-protective [32-34]. The dose of arsenic selected in the present study is quite low and based on the earlier studies $[35,36]$. Although a number of studies have been carried out to understand the protective efficacy of herbal agents against arsenic induced toxicity, not much is known about its mechanism involved in immunotoxicity and protective management. In recent years, the intake of dietary polyphenols has received a great attention of health scientists to use them in the therapeutic management of various disease conditions. The present study has therefore been focused to investigate the immunomodulatory role of the fruit extract of amla in arsenic induced oxidative damage including lipid peroxidation, status of antioxidant enzymes and mitochondrial membrane potential and apoptosis and necrosis in thymocytes of mice.

\section{Methods}

Chemicals

Sodium arsenite, RNase A, 2',7'-dichlorofluorescein diacetate (DCFH-DA), 3-(4,5-dimethyl-2-yl)- 2,5-diphenyl tetrazolium bromide (MTT), 7-amino-4-trifluoro methylcoumarin (AFC), DPPH (1,1-diphenyl-2-2'-picrylhydrayl) and all other chemicals were purchased from Sigma-Aldrich, USA. Rhodamine 123 (Rh 123) and from Molecular Probes, propidium iodide (PI) from Calbiochem, and Annexin V-FITC were purchased from Biovision.

\section{Plant material}

Studies have been reported that phenolics and flavonoids including gallic acid, ellagic acid, isocorilagin, chebulanin and chebulagic acid are the major constituents present in ethyl acetate extract of amla [37,38]. To investigate the combined effect of theses constituents, ethyl acetate extract of amla has been selected for the present study. Briefly, the fresh fruits of amla were collected from authentic source and fruit powder was extracted three times using 95\% ethanol (Plant Identification No. - 13394 obtained by the Herbarium of Birbal Sahni Institute of Palaeobotany, Lucknow, India). The combined extracts were filtered and evaporated to dryness with a rotary evaporator under reduced pressure and the residue was suspended in water and extracted successively with diethyl ether and ethyl acetate. The extract was evaporated under reduced pressure to get powdered form of ethyl acetate fraction.

\section{Animals and treatment}

The Balb/c male mice ( $15 \pm 2 \mathrm{~g})$ were obtained from the animal breeding colony of CSIR-Indian Institute of Toxicology Research, Lucknow used for the study. Mice were housed in an air-conditioned room at $25 \pm 2{ }^{\circ} \mathrm{C}$ with a $12 \mathrm{~h}$ light/dark cycle under standard hygiene conditions and had free access to pellet diet and water ad libitum. The study was approved by the institutional animal ethics committee of King George Medical University, Lucknow (No. 121 IAH/Pharma-11) and all experiments were carried out in accordance with the guidelines laid down by the committee for the purpose of control and supervision of experiments on animals (CPCSEA), Ministry of Environment and Forests (Government of India), New Delhi, India. The animals were randomly divided into four groups contained ten animals in each group as follows

Group I. Mice were treated with vehicle ( $2 \%$ gum acacia) for the duration of the treatment to serve as controls.

Group II. Mice were treated with arsenic as sodium arsenite (dissolved in distilled water $3 \mathrm{mg} / \mathrm{kg}$ body weight p.o., daily for 30 days). 
Group III. Mice were treated with fruit extract of amla (500 mg/kg body weight, suspended in $2 \%$ gum acacia, p.o., daily for 30 days).

Group IV. Mice were co-treated with arsenic and fruit extract of amla identically as in group II and III.

After the last dose of treatment, animals were sacrificed and thymus of all the animals was isolated. Out of all isolated thymus three of each set, put into the phosphate buffer saline (PBS) and processed for the measurement of apoptotic parameters. While remaining thymus were immediately placed in an ice cold saline solution $(0.15 \mathrm{M})$, blotted on filter paper, quickly weighed and processed for enzymatic and non-enzymatic antioxidants assays.

\section{Preparation of thymocyte suspension}

Thymus was dissected from mice and single cell suspension was prepared under aseptic condition. The suspension was passed through stainless steel mesh centrifuged at $200 \times$ g at $4^{\circ} \mathrm{C}$ for $10 \mathrm{~min}$ and resuspended in complete cell culture medium (RPMI-1640 containing HEPES and $2 \mathrm{mM}$ glutamine, supplemented with $10 \%$ FBS and $1 \%$ antibiotic antimycotic solution) the cell density were adjusted to $1.5 \times 10^{6} \mathrm{cell} / \mathrm{ml}$.

\section{Measurement of antioxidant activity \\ Assay of DPPH radical scavenging activity}

The free radical scavenging activity of ethyl acetate extract amla was measured by the scavenging of the DPPH radical using the standard method with slight modifications [39]. Amla extract at different concentrations (1.0, $2.5,5,10,20$ and $40 \mu \mathrm{g} / \mathrm{ml})$ in ethanol $(2 \mathrm{ml})$ was mixed with DPPH (2 ml, $1 \mathrm{mM}$ in ethanol) and incubated for 30 min in the dark. The absorbance of DPPH radical was read at $517 \mathrm{~nm}$ using a spectrophotometer. The DPPH radical scavenging activity was calculated using the following equation

$$
\text { Scavenging activity }(\%)=\left\{\left(A_{0}-A_{1}\right) / A_{0}\right\} \times 100
$$

where $A_{0}$ is the absorbance of the control reactions and $A_{1}$ is the absorbance in the presence of the test compound.

\section{Biochemical parameters \\ Assessment of cell viability}

The cell viability was measured by the MTT reduction method following the standard procedure [40]. Cells were seeded at a density of $1.0 \times 10^{4}$ in a 96 well plate. $10 \mu \mathrm{l}$ of MTT ( $5 \mathrm{mg} / \mathrm{ml} \mathrm{PBS}$ ) was added to the each well and incubated for $4 \mathrm{~h}$ at $37^{\circ} \mathrm{C}$ in a $\mathrm{CO}_{2}$ incubator. The plate was centrifuged at $1200 \times \mathrm{g}$ for $10 \mathrm{~min}$ and $100 \mu \mathrm{l}$ of DMSO was added after aspirating supernatant to dissolve the formazan formed in the wells. After 5 min the absorbance was read on a microplate reader (Synergy HT of BIO-TEK International, USA) at $530 \mathrm{~nm}$.

\section{Assay of lipid peroxidation}

Lipid peroxidation as a measure of thiobarbituric acid reactive substances was measured following the standard procedure [41]. Malondialdehyde (MDA) forms as an intermediate product of the peroxidation of lipids and serves as an index of the intensity of oxidative stress. The intensity of pink color formed during the reaction was read on a spectrophotometer at $532 \mathrm{~nm}$.

\section{Assay of reduced glutathione levels}

Levels of reduced glutathione (GSH) in the thymus homogenate were estimated following the standard protocol [42]. The assay involves the reaction of GSH with 5, 5' dithiobis-2 nitrobenzoic acid (DTNB) that forms yellow color and its absorbance was taken by spectrophotometer at $412 \mathrm{~nm}$. The result has been expressed at $\mu \mathrm{g} \mathrm{GSH} / \mathrm{mg}$ protein.

\section{Assay of superoxide dismutase activity}

Activity of superoxide dismutase in thymus homogenate was assayed according to the method of Marklund and Marklund [43]. The unit of enzyme activity is defined as the enzyme required for $50 \%$ inhibition of pyrogallol autooxidation. The results have been expressed as unit/min/ mg protein.

\section{Assay of catalase activity}

Activity of catalase in thymus homogenate was assayed following the standard protocol [44] using hydrogen peroxide $\left(\mathrm{H}_{2} \mathrm{O}_{2}\right)$ as substrate. The activity of catalase was measured on a spectrophotometer and has been expressed in $\mu \mathrm{mole} / \mathrm{min} / \mathrm{mg}$ protein.

\section{Assay of caspase-3 activity}

Activity of caspase-3 in thymocytes was measured following the standard procedure described by Pathak and Khandelwal [45]. Briefly, the cells $\left(3.0 \times 10^{6} / \mathrm{ml}\right)$ were lysed on ice for $10 \mathrm{~min}$ with the help of lysis buffer. Further, the reaction buffer $(10 \mathrm{mM}$ Tris- $\mathrm{HCl}, 1 \mathrm{mM}$ EDTA, $10 \mathrm{mM}$ DTT, $5 \%$ glycerol) and DEVD-AFC substrate $(50 \mu \mathrm{M})$ were added and incubated at $37^{\circ} \mathrm{C}$ in dark for $2 \mathrm{~h}$. AFC was used as standard and fluorescence was measured at excitation and emission wavelengths of $400 \mathrm{~nm} / 505 \mathrm{~nm}$, respectively, on a microplate reader. The enzyme activity is expressed as nmoles AFC/60 min.

\section{Assay of cytochrome c oxidase activity}

Cytochrome c oxidase activity was assayed through the colorimetric assay kit purchased from Sigma-Aldrich Chemical Co. (St. Louis, MO, USA). Absorbance was 
measured on a spectrophotometer at $550 \mathrm{~nm}$ and values are expressed as $\mathrm{U} / \mathrm{ml}$.

\section{Assay of ROS generation}

The generation of ROS was measured using DCFH-DA by flow cytometry as described previously [46]. Single cell suspension $\left(1 \times 10^{6} / \mathrm{ml}\right)$ of thymus from control and treated mice was suspended in PBS and incubated with DCFH-DA at $37^{\circ} \mathrm{C}$ for $1 \mathrm{~h}$. Hydrolysis of DCFH-DA leads to formation of fluorescence DCFH that was measured by the fluorescence intensity (FL-1, $530 \mathrm{~nm}$ ).

\section{Assay of mitochondrial membrane potential}

The detection of mitochondrial membrane potential was assessed by flow cytometry following the standard procedure [47]. Single cell suspension $\left(1 \times 10^{6} / \mathrm{ml}\right)$ was incubated with $\mathrm{Rh}-123$ for $60 \mathrm{~min}$ in dark at $37^{\circ} \mathrm{C}$. The mitochondrial membrane potential was measured using FL-1 filter at fluorescence intensity of $530 \mathrm{~nm}$.

\section{Analysis of apoptotic DNA}

The assay of apoptotic DNA was carried out using the standard procedure [48]. Briefly, cell suspension of thymocytes at a density of $1 \times 10^{6}$ cells from control and treated mice was prepared for the detection of cell cycle analysis. Cells were washed with PBS and fixed by $70 \%$ ethanol. The fixed cells were again washed with PBS and added phosphate citrate buffer $(200 \mu \mathrm{l}, \mathrm{pH} 7.8)$ and incubated for $60 \mathrm{~min}$ at room temperature. After centrifugation the cells were resuspended in $0.5 \mathrm{ml}$ propidium iodide (PI) and $0.5 \mathrm{ml} \mathrm{RNAse}(50 \mu \mathrm{g} / \mathrm{ml})$ and further incubated for $30 \mathrm{~min}$ in the dark. The PI fluorescence was measured through a FL-2 filter (585 nm) and a total of 10,000 events were acquired.

\section{Assessment of apoptotic and necrotic cell}

The apoptotic and necrotic cell distribution was analyzed through Annexin V binding and PI uptake following the procedure of Vermes et al. [49]. Briefly, thymocytes were suspended in $1 \mathrm{ml}$ binding buffer $(1 \times)$, an aliquot of $100 \mu \mathrm{l}$ was incubated with $5 \mu \mathrm{l}$ Annexin V-FITC and $10 \mu \mathrm{l}$ PI for 15 min in dark at room temperature and $400 \mu \mathrm{l}$ binding buffer $(1 \times)$ was added to each sample, the FITC and PI fluorescence will be measured through FL-1 (530 nm) and FL-2 filters $(585 \mathrm{~nm})$ respectively.

\section{Protein estimation}

Protein concentration in thymus homogenates was measured following the standard procedure [50] using bovine serum albumin as the reference standard.

\section{Statistical analysis}

The statistical analysis was carried out by GraphPad Prism 3.02 using one way analysis of variance followed by Newman-Keuls test for multiple pair wise comparisons among the groups. All values have been expressed as mean \pm SEM. $P$ value $<0.05$ has been considered significant.

\section{Results}

\section{Effect on DPPH free radical scavenging activity}

The different concentration of ethyl acetate extract of amla $(1.0,2.5,510,20$ and $40 \mu \mathrm{g} / \mathrm{ml})$ in ethanol (2 ml) was used for the DPPH radical scavenging activity and results were presented in Figure 1. The 50\% inhibitory concentration $\left(\mathrm{IC}_{50}\right.$ ) of fruit extract was found to be $8.32 \mu \mathrm{g} / \mathrm{ml}$ and it become saturated over $20 \mu \mathrm{g} / \mathrm{ml}$ concentration where the activity was more than $90 \%$. The results showed that ethyl acetate extract of amla has strong free radical scavenging activity associated with its antioxidant potential.

\section{Effect on body weight and thymus weight in mice}

Effect of arsenic and co-treatment of arsenic and amla on mice has been presented in Table 1. Exposure to arsenic in mice caused a significant decrease in body weight (25\%, $\mathrm{p}<0.01)$ and thymus weight $(34 \%, \mathrm{p}<0.001)$ as compared to controls suggesting the general toxic effect of the arsenic and could be associated with decreased food consumption and water intake. Co-treatment with arsenic and amla increased the body weight $(21 \%, \mathrm{p}<0.05)$ and thymus weight $(26 \%, \mathrm{p}<0.05)$ as compared to mice treated with arsenic alone. No significant effect on body weight and thymus weight was observed in mice treated with amla alone as compared to controls (Table 1).

\section{Effect on cell viability in thymus of mice}

Effect of arsenic and co-treatment of arsenic and amla on cell viability in thymus has been presented in Figure 2. Mice exposed to arsenic exhibited a significant decrease in cell viability $(34 \%, \mathrm{p}<0.001)$ as compared to controls. Co-treatment with arsenic and amla increased the cell viability $(21 \%, \mathrm{p}<0.01)$ in thymus as compared to those

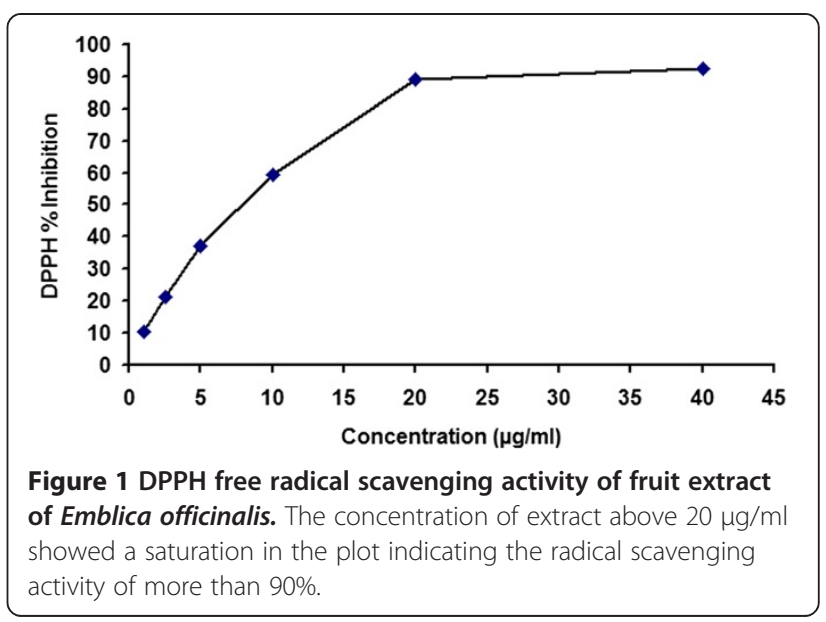


Table 1 Effect on body, thymus weight and thymus cellularity in mice exposed to arsenic, amla and their co-treatment for 30 days

\begin{tabular}{|c|c|c|c|c|}
\hline \multirow[t]{3}{*}{ Parameters } & \multirow[t]{3}{*}{ Control } & \multicolumn{3}{|c|}{ Treatment groups } \\
\hline & & Arsenic & Amla & Amla \\
\hline & & $(3 \mathrm{mg} / \mathrm{kg})$ & $(500 \mathrm{mg} / \mathrm{kg})$ & + Arsenic \\
\hline Body weight (g) & $19.40 \pm 1.12$ & $15.40 \pm 0.97^{* a}$ & $19.80 \pm 0.80$ & $18.60 \pm 1.16^{* b}$ \\
\hline Thymus weight (mg) & $79.2 \pm 3.73$ & $52.2 \pm 3.26^{* a}$ & $77.6 \pm 3.29$ & $66.2 \pm 4.54^{* b}$ \\
\hline Thymus cellularity $(\times 10)^{-6}$ & $32.3 \pm 6.60$ & $26.2 \pm 5.30^{* a}$ & $33.1 \pm 5.20$ & $30.6 \pm 4.80^{* b}$ \\
\hline
\end{tabular}

Values are mean \pm SEM of five animals in each group.

*a-compared to control group; *b-compared to arsenic treated group.

*Significantly differs $(p<0.05)$.

treated with arsenic alone. No significant effect on cell viability was observed in mice treated with amla alone as compared to controls (Figure 2).

\section{Effect on the lipid peroxidation in thymus of mice}

To assess the level of oxidative damage to the biological membrane, effect of arsenic and co-treatment of arsenic and amla on lipid peroxidation in thymus has been carried out and presented in Figure 3. A significant increase in lipid peroxidation $(52 \%, \mathrm{p}<0.001)$ in thymus was observed in mice exposed to arsenic as compared to controls. Co-treatment with arsenic and amla decreased in the level of lipid peroxidation $(36 \%, \mathrm{p}<0.001)$ in thymus as compared to those treated with arsenic alone. No significant effect on the level of lipid peroxidation was observed in mice treated with amla alone as compared to controls (Figure 3).

\section{Effect on the reduced glutathione levels in thymus of mice} Arsenic has high affinity to GSH and thus enhances vulnerability towards oxidative stress. Figure 4 indicates the effect of arsenic and co-treatment of arsenic and amla on reduced glutathione levels in thymus of mice. Exposure to arsenic in mice caused a significantly decreased in the levels of reduced glutathione $(34 \%, \mathrm{p}<0.001)$ in thymus as compared to controls. Co-treatment with arsenic and amla increase the levels of reduced glutathione (49\%, $\mathrm{p}<0.001$ ) in thymus of mice as compared to those treated with arsenic alone. No significant effect on the levels of

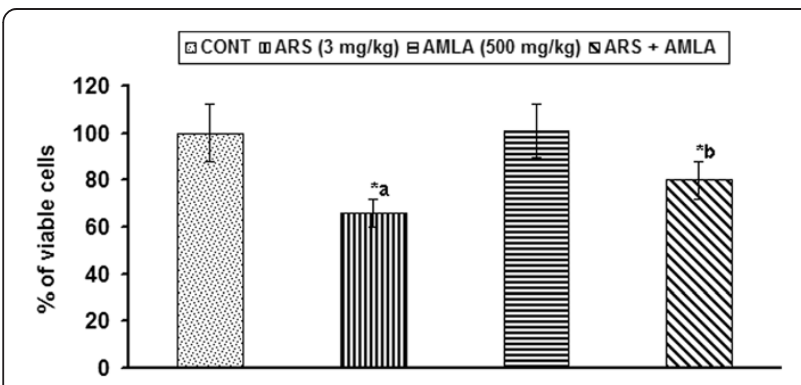

Figure 2 Effect of arsenic, amia and their co-treatment on cell viability in thymus of mice. Values are mean \pm SEM of five animals in each group a-compared to control group, b-compared to arsenic treated group *Significantly differs $(p<0.05)$. reduced glutathione was observed in the thymus of mice treated with amla alone as compared to controls (Figure 4).

\section{Effect on the activity of superoxide dismutase in thymus of mice}

Effect of arsenic and co-treatment of arsenic and amla on the activity of superoxide dismutase in thymus has been presented in Figure 5. The activity of superoxide dismutase, an enzyme involved in the dismutation of superoxide radicals, was found to be significant decreased $(31 \%, \mathrm{p}<0.01)$ in thymus of mice exposed to arsenic as compared to controls. Co-treatment with arsenic and amla increased the activity of superoxide dismutase (36\%, $\mathrm{p}<0.05)$ in thymus as compared to those treated with arsenic alone. No significant effect on the activity of superoxide dismutase was observed in the thymus of mice treated with amla alone as compared to controls (Figure 5).

\section{Effect on the activity of catalase in thymus of mice}

Effect of arsenic and co-treatment of arsenic and amla on the activity of catalase in thymus has been presented in Figure 6. Exposure to arsenic in mice caused a significant decrease the activity of catalase $(35 \%, \mathrm{p}<0.05)$ in thymus of mice as compared to controls. Co-treatment with arsenic and amla increased the activity of catalase in thymus $(32 \%, \mathrm{p}<0.05)$ as compared to those treated

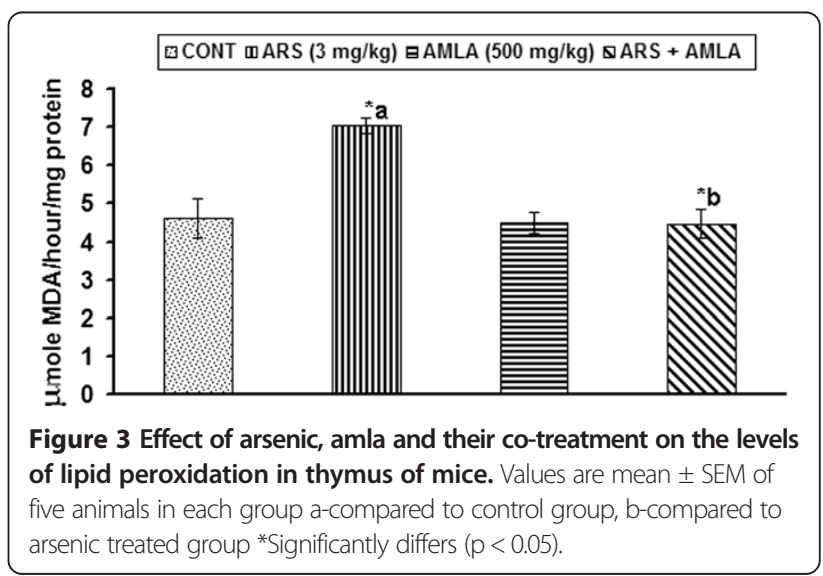




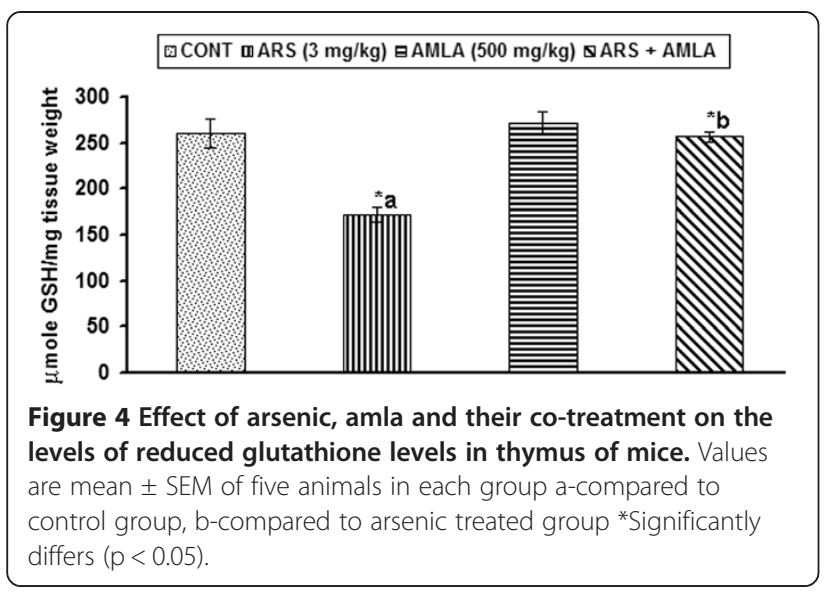

with arsenic alone suggesting a protective effect of amla against oxidative insult. No significant effect on the activity of catalase was observed in the thymus of mice treated with amla alone as compared to controls (Figure 6).

\section{Effect on caspase-3 activity in thymus of mice}

Figure 7 demonstrate the effect of arsenic and co-treatment of arsenic and amla on the activity of caspase- 3 in thymus of mice. Exposure to arsenic caused a significant increased in the caspase activity $(2.42$ fold, $\mathrm{p}<0.001)$ in thymus of mice as compared to controls. Co-treatment with arsenic and amla decrease the activity of caspase $(0.3$ fold, $\mathrm{p}<0.01)$ in thymus as compared to mice treated with arsenic alone suggesting a trend of recovery. No significant effect on the caspase activity was observed in mice treated with amla alone as compared to controls (Figure 7).

Effect on cytochrome c oxidase activity in thymus of mice Effect of arsenic and co-treatment of arsenic and amla on the cytochrome c oxidase activity in thymus has been presented in Figure 8. Exposure of arsenic in mice showed a decreased cytochrome c oxidase activity $(43 \%, \mathrm{p}<0.001)$ in thymus as compared to controls. Co-treatment with arsenic and amla increased the cytochrome c oxidase activity $(62 \%, \mathrm{p}<0.001)$ in thymus as compared to mice

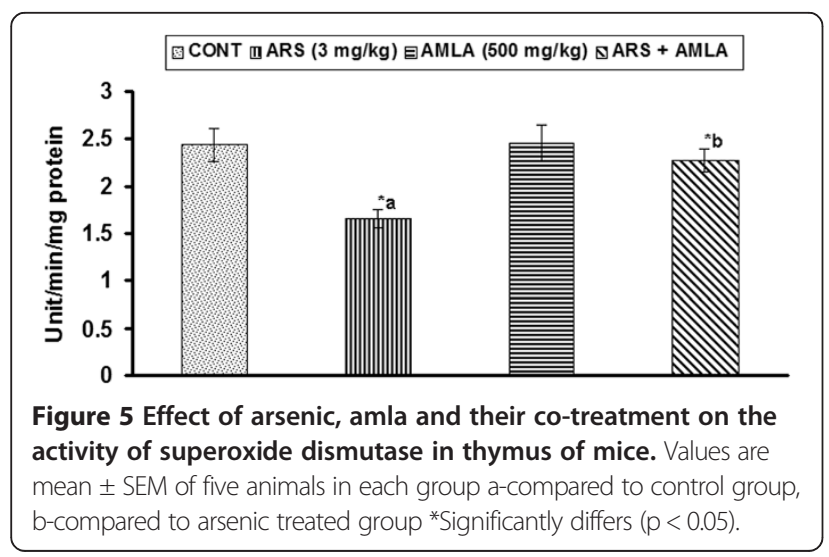

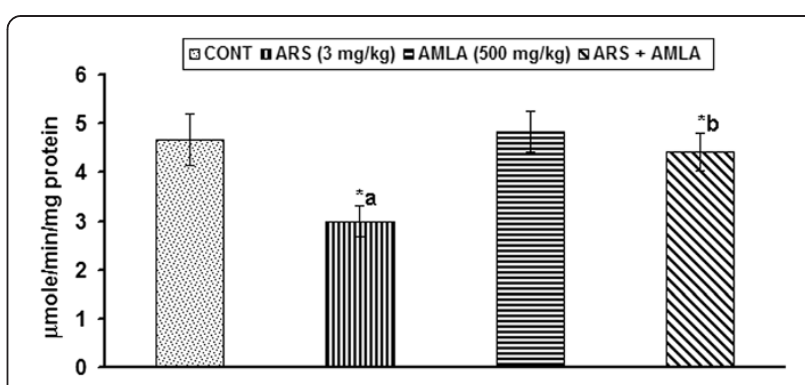

Figure 6 Effect of arsenic, amla and their co-treatment on the catalase activity in thymus of mice. Values are mean \pm SEM of five animals in each group a-compared to control group, b-compared to arsenic treated group *Significantly differs $(p<0.05)$.

treated with arsenic alone. No significant effect on the cytochrome c oxidase activity was observed in mice treated with amla alone as compared to controls (Figure 8).

\section{Effect on the generation of ROS in thymus of mice}

Arsenic has been found to be associated with the increased generation of ROS. Effect of arsenic and co-treatment of arsenic and amla on ROS generation in thymus has been presented in Figure 9. Exposure of arsenic to mice caused an increased generation of ROS $(90 \%, \mathrm{p}<0.01)$ in thymus as compared to controls. Co-treatment with arsenic and amla decreased the ROS generation $(52 \%, \mathrm{p}<0.01)$ in thymus as compared to mice treated with arsenic alone suggested the antioxidant and free radical scavenging activity of amla. No significant effect on the production of ROS was observed in mice treated with amla alone as compared to controls (Figure 9).

\section{Effect on the mitochondrial membrane depolarization in thymus of mice}

Effect of arsenic and co-treatment of arsenic and amla on mitochondrial membrane depolarization in thymus has been presented in Figure 10. Exposure of arsenic in mice showed decrease mitochondrial membrane depolarization $(53 \%, \mathrm{p}<0.001)$ in thymus as compared to controls. Co-treatment with arsenic and amla increased

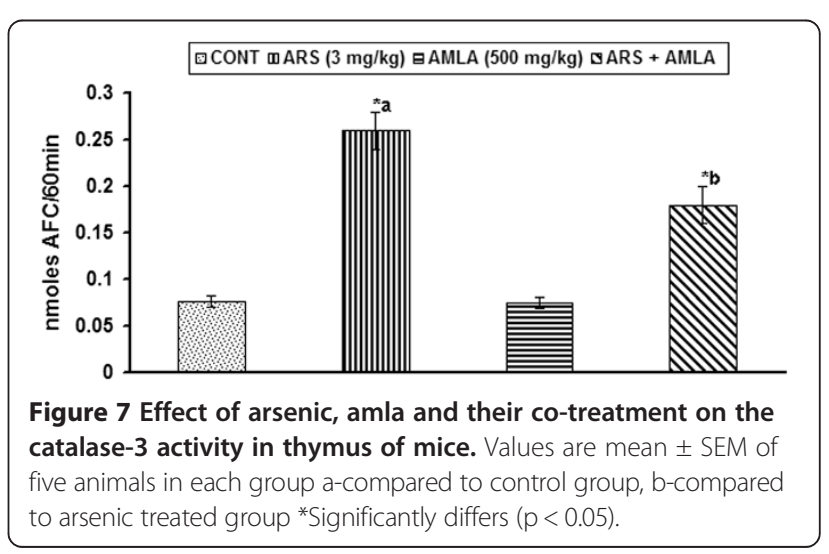




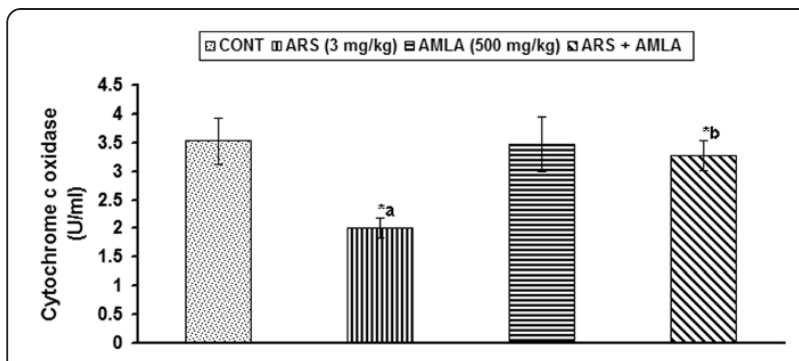

Figure 8 Effect of arsenic, amla and their co-treatment on the cytochrome c oxidase activity in thymus of mice. Values are mean \pm SEM of five animals in each group a-compared to control group, $b$-compared to arsenic treated group *Significantly differs $(p<0.05)$.

the mitochondrial membrane depolarization (43\%, p < 0.05 ) in thymus as compared to mice treated with arsenic alone. No significant effect on the mitochondrial membrane depolarization was observed in mice treated with amla alone as compared to controls (Figure 10).

\section{Effect on the cell cycle in thymus of mice}

Cell cycle represents the DNA damage in cells in sub G1 peak. Figure 11 demonstrate the effect of arsenic and cotreatment of arsenic and amla on the DNA damage as observed by a sub G1 peak in thymus. Exposure of arsenic to mice caused an increased number of sub G1 peak indicating the DNA damage $(21.37 \%, \mathrm{p}<0.01)$ in thymus as compared to controls. Co-treatment with arsenic and amla reduced the number of cells in sub G1 peak $(11.67 \%, \mathrm{p}<0.01)$ in thymus as compared to mice treated with arsenic alone. No significant effect on the cell cycle was observed in mice treated with amla alone as compared to controls (Figure 11).

\section{Effect on the annexin V/PI binding assay in thymus of mice} Annexin binding assay has been used to measure the number of apoptosis and necrotic cells. Effect of arsenic and cotreatment of arsenic and amla on the apoptosis in thymus has been presented in Figure 12. Exposure of arsenic in mice caused an increased number of necrotic (9\%) and apoptotic cells $(11.52 \%)$ in thymus as compared to controls. Co-treatment with arsenic and amla decreased the number of necrotic (2.03\%) and apoptotic cells (3.34\%) in thymus as compared to mice treated with arsenic alone. No significant effect of apoptosis and necrosis in cells of the thymus was observed in mice treated with amla alone as compared to controls (Figure 12).

\section{Discussion}

Enhanced oxidative stress has been found to play a crucial role in the induction of apoptosis under both pathological
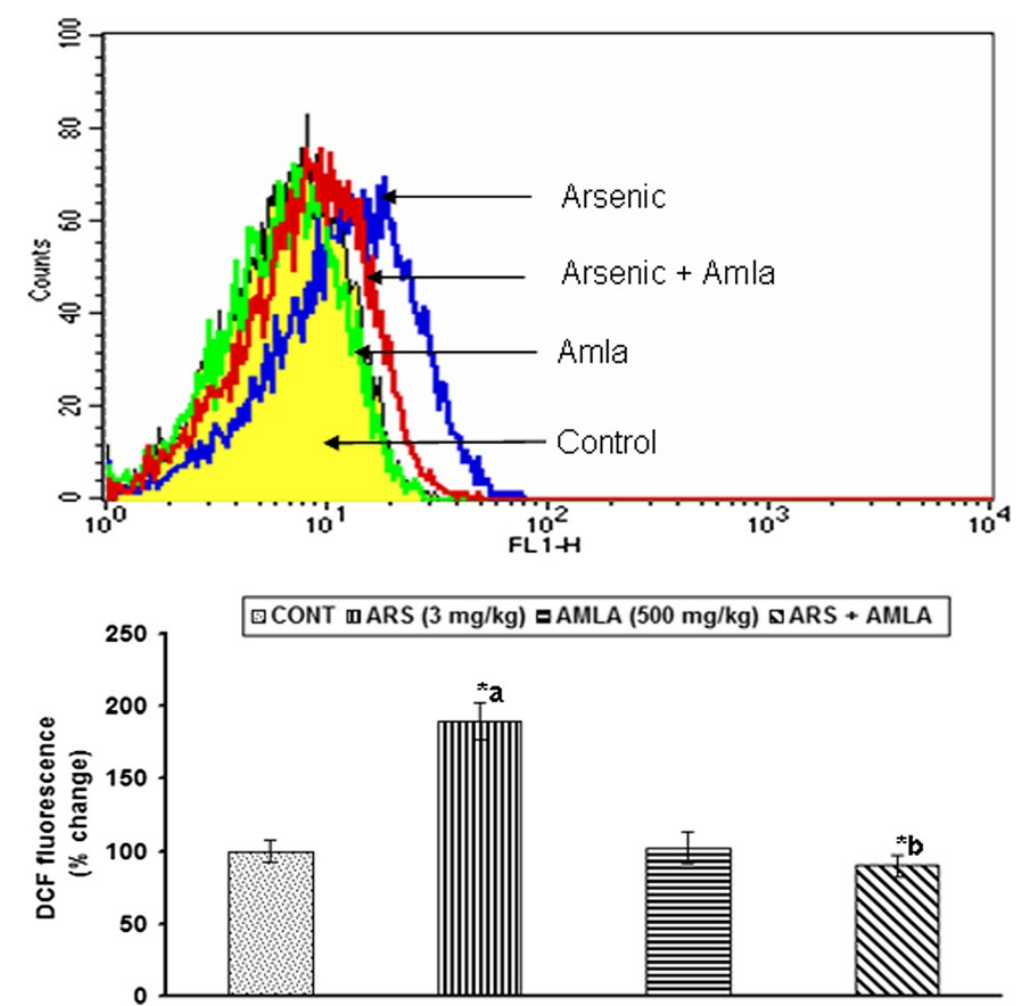

Figure 9 Effect of arsenic, amla and their co-treatment on the generation of reactive oxygen species in thymocytes of mice. Cells were incubated with DCFH-DA and fluorescence was measured using a flow cytometer with FL-1 filter. Values are presented as mean \pm SEM of three assays performed independently a-compared to control group, b-compared to arsenic treated group *Significantly differs $(p<0.05)$. 

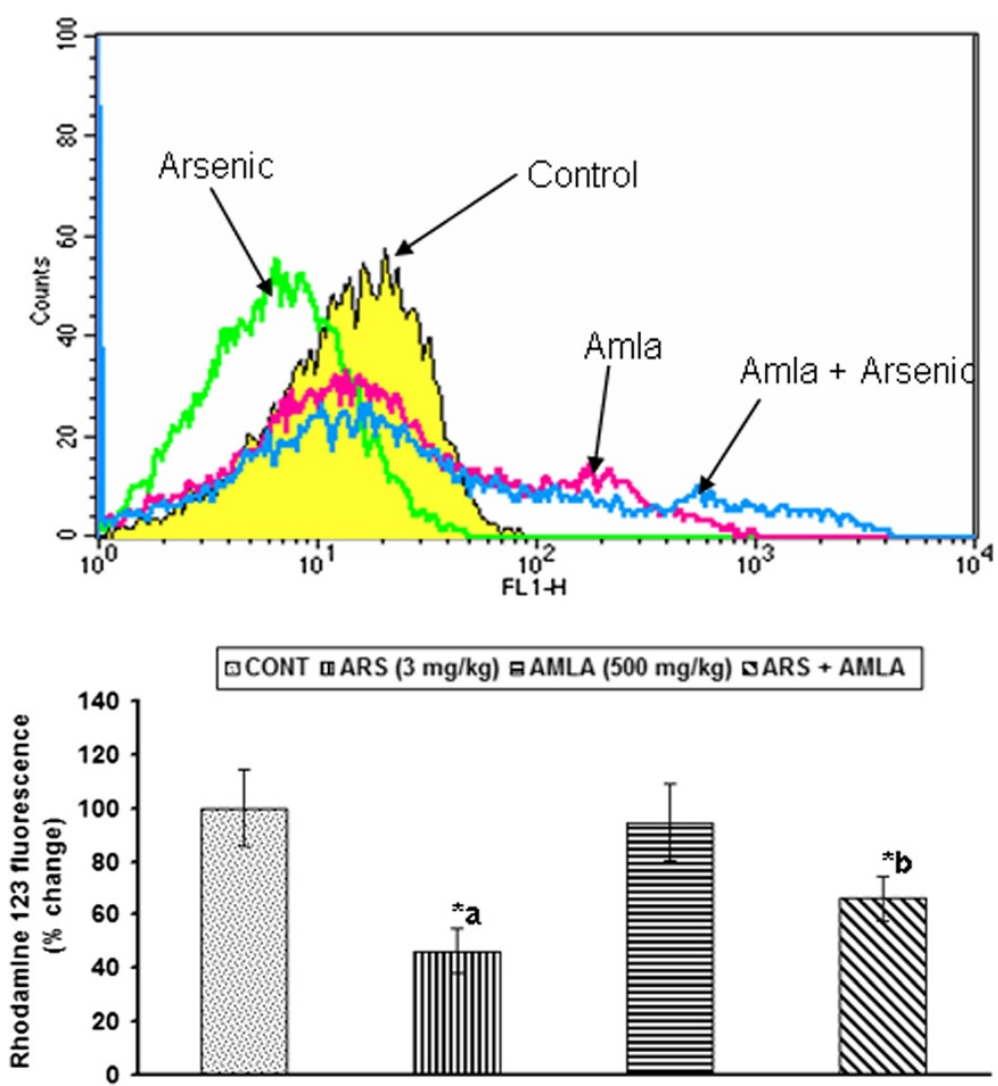

Figure 10 Effect of arsenic, amla and their co-treatment on mitochondrial membrane potential of thymocytes of mice. Cells were incubated with Rh 123 and fluorescence was measured using flow cytometer with FL-1 filter. Values are presented as mean \pm SEM of three assays performed independently a-compared to control group, b-compared to arsenic treated group *Significantly differs $(p<0.05)$.

and physiological conditions. Increased generation of free radicals associated with enhanced oxidative stress has been found to be implicated in arsenic induced thymic atrophy $[20,21]$. Numerous studies have reported that exposure to arsenic increased the production of free radical generation and cause oxidative damage to the biological membrane through increased levels of lipid peroxidation, protein carbonyl contents followed by decreased antioxidant defense system $[20,21,28]$. GSH is an important biomolecule involve in the antioxidant defense system against toxicants. The decrease in the levels of GSH following exposure to arsenic has been found to be associated with high affinity of arsenic with GSH [51]. Chronic arsenic exposure has largely been associated with the apoptosis in the lymphocytes and involve in immunotoxic response. Viability of cells has been found to be decreased in thymus of mice following exposure to arsenic as observed in the present study suggested the immunotoxicity of arsenic. Increased production of ROS associated with enhanced lipid peroxidation and decreased levels of reduced glutathione, the activity of superoxide dismutase and catalase as observed in the present study consistent with the earlier findings $[20,21]$. Most of the toxic chemicals directly act on the mitochondria, disrupt its phospholipids membrane and cause mitochondrial dysfunctions [2,52,53]. Arsenic compounds have been shown to be strong inducers of apoptosis in normal and transformed cells through production of ROS [54], decreased mitochondrial membrane potential [52], activation of caspases [25,55], increased fragmentation of DNA [55], decreased expression of anti-apoptotic proteins (Bcl-2, Bcl-XL) and increased expression of proapoptotic proteins [55]. Martin-Chouly et al. [56] reported that inorganic arsenic directly acts on human T-cells and impaired their activity via up-regulation of several immune and stress response genes. However, the inhibition of $\mathrm{T}$ cell proliferation was independently of heme oxygenase -1 expression and monocyte related accessory signals [56]. Exposure to arsenic through semiconductor elements including indium arsenide and gallium arsenide could induce alterations in gene expression and immune response associated with increased production of ROS which might be involved in the apoptosis and necrosis in T-lymphocytes and neuronal cells [57,58]. A decreased in the activity of cytochrome c oxidase, mitochondrial membrane potential and increased activity of mitochondrial caspase-3, number of cells in sub G1 peak and 

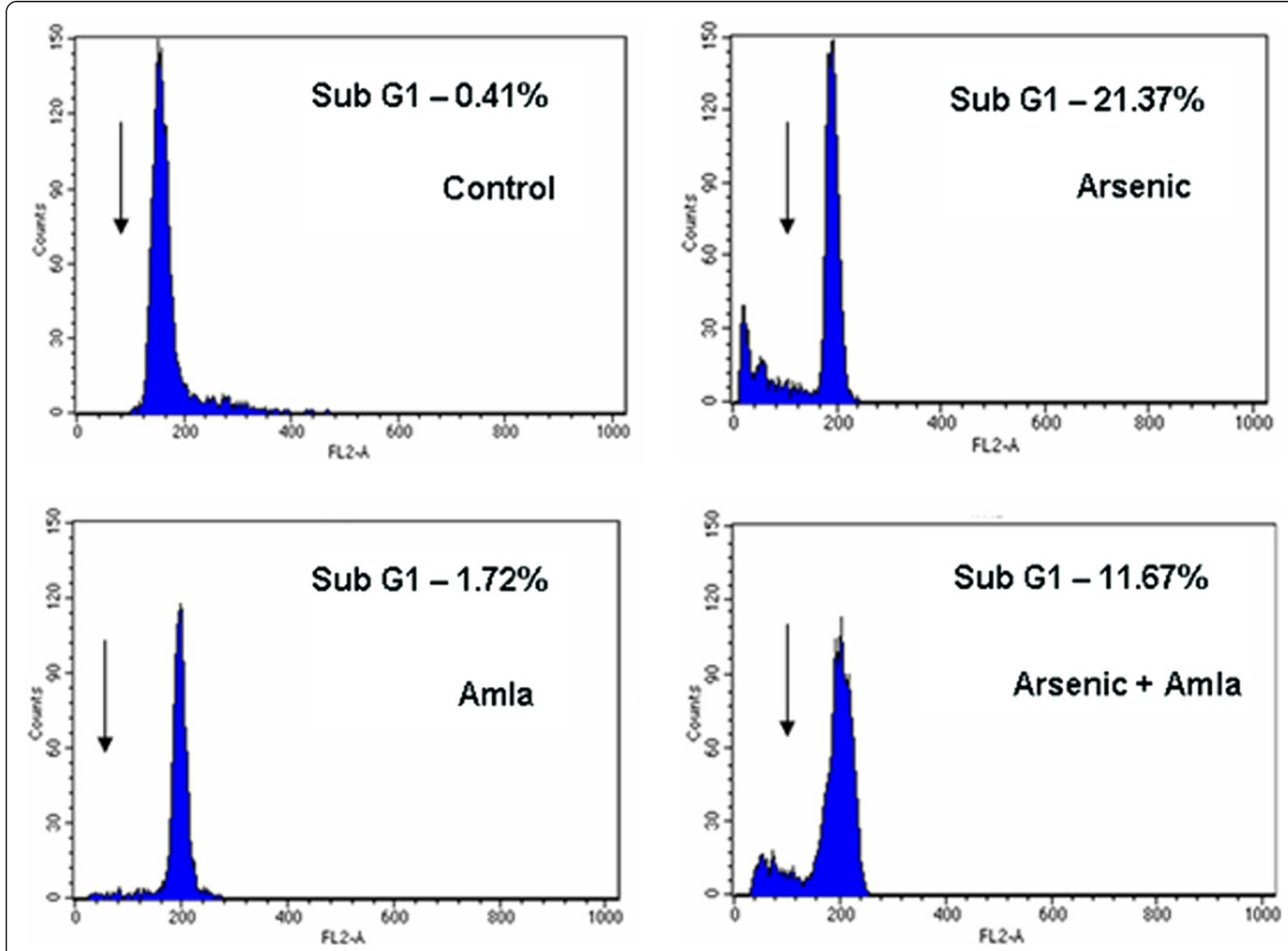

Figure 11 Effect of arsenic, amla and their co-treatment on the cell cycle progression of thymocytes of mice. Control and amla treated cells showed no sub-G1 peak while arsenic showed high numbers of cells in sub-G1 peak and group co-treated with of arsenic and amla showed reduce number of cells in sub-G1 peaks as compared to arsenic. Cells were incubated with propidium iodide and flourescence was measured using flow cutometer with FL-2 filter. Values are presented in the historam as mean \pm SEM of three assays performed independently representing sub-G1 population of cells.

number of apoptotic and necrotic cells following exposure to arsenic in mice as observed in the present study is consistent with the earlier reports.

Experimental studies have reported that weight of organs (thymus, spleen, adrenals) responsible for immune response was decreased following exposure to arsenic $[20,59]$. Subchronic low-level exposure to arsenic may affect immune responses [59]. Decrease body weight in experimental animals exposed to arsenic has been reported [59-61]. Decrease in the body weight indicates the general toxic effect of the chemical. A decrease in the body weight and thymus weight as observed in the present study could be due to immunotoxic response of arsenic that have been found to be recovered by co-treatment with amla and arsenic in mice.

Various pharmacological preparations and plant extracts are reported to have strong antioxidant potential and used against arsenic induced oxidative damage to investigate their protective efficacy $[2,21,30]$. Phyto constituents including flavanoids found in the plant extracts are effective as radical scavengers and inhibitors of lipid peroxidation [61-63]. Amla contains a wide variety of phenolics and its derivatives associated with its strong antioxidant potential. Amla is widely accepted immune booster among the people since it possesses multiple pharmacological and immunomodulatory properties [21,30-33]. It has been reported that amla protects against the harmful action of free radicals and exhibit its ameliorating effects in biological system [32,33]. Sharma et al. [21] reported that the antioxidant potential of amla may be due to the presence of the many phyto-constituents, which provide maximum conjugation with free radical species, thus reducing the number of free radicals available and the extent of cellular damage. They further suggested that pre and post supplementation of fruit extract of amla significantly reduce arsenic induced oxidative stress in the liver as a result serum transaminases and MDA content become lowered in the liver and also increased activity 


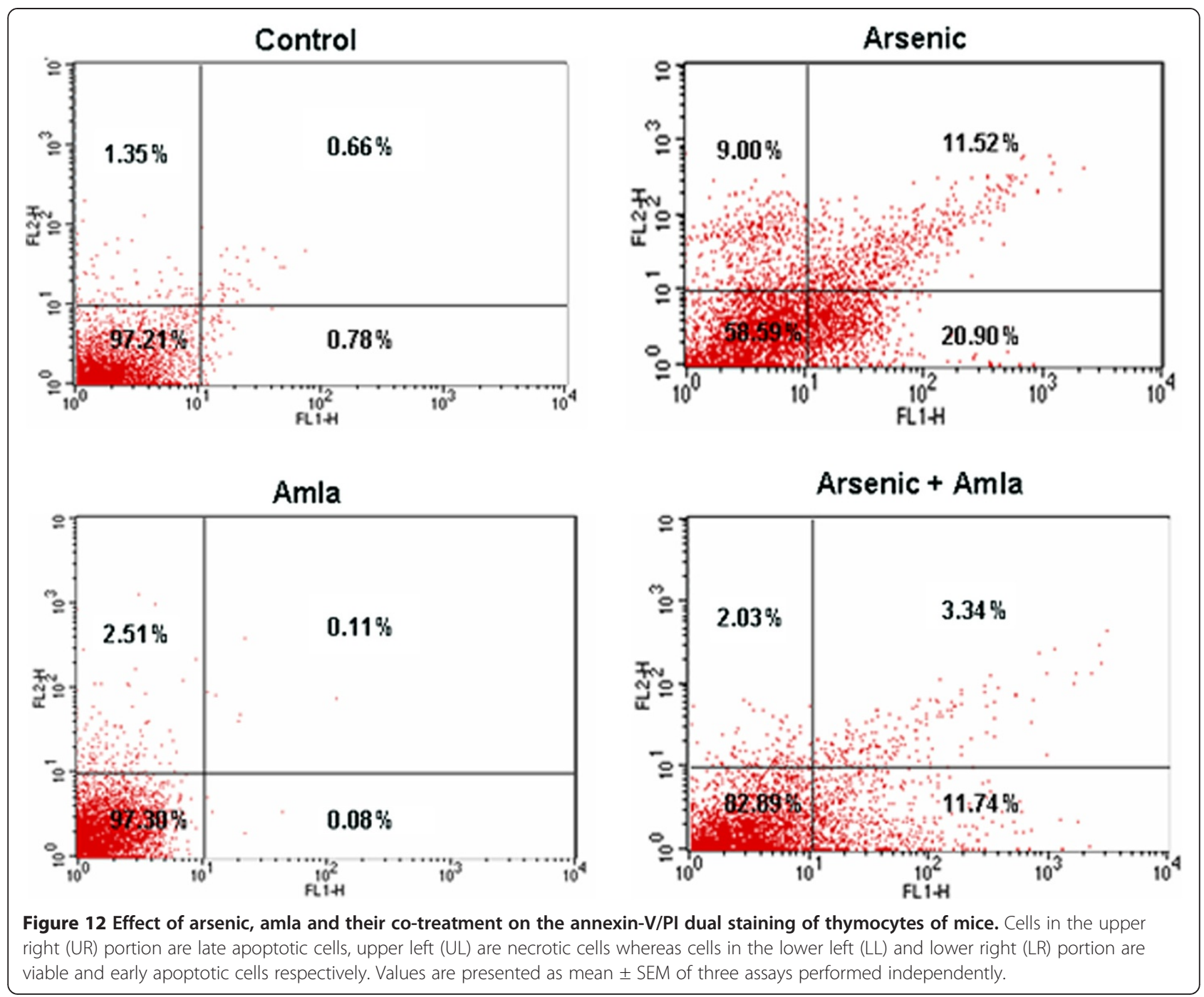

of superoxide dismutase, catalase, glutathione $S$ transferase and serum alkaline phosphatase activities [21]. Reddy et al. [64] reported that alcohol-induced oxidative stress in plasma of rats could be ameliorated through the amla that could be due to the combined effect of phytophenols present in it. In another study, Kumar et al. [65] found that amla significantly protects against lead induced toxicity by decrease generation of free radicals in one day old male broiler chicks. Haque et al. [66] suggested that amla extract was very effective in reducing cyclophosphamide induced suppression of humoral immunity in mice. They also reported that amla extract treatment in normal animals could modulate levels of certain antioxidants of kidney and liver resulted in restoration of antioxidant enzymes in cyclophosphamide treated animals and further suggested that amla or its medicinal preparations may be useful in combination therapy in cancer patients. The supplementation with Triphala (Terminalia chebula, Terminalia belerica and Emblica officinalis) prevents the noise-stress induced changes in the antioxidant as well as cell-mediated immune response in rats [67]. Enhanced lipid peroxidation and decreased levels of reduced glutathione, activity of superoxide dismutase and catalase following exposure to arsenic has been found to be protected following simultaneous treatment with arsenic and amla in mice suggesting protective efficacy of amla.

In the present study, treatment with amla alone had no significant effect on cell viability, lipid peroxidation, levels of reduced glutathione, the activity of superoxide dismutase, Catalase and other apoptotic markers including the activity of caspase- 3 and cytochrome c oxidase. However, decreased cell viability has been found to be protected following co-treatment with arsenic and amla in thymus of mice. Also, increased levels of lipid peroxdation, activity of caspase- 3 and decreased levels of reduced glutathione, activity of superoxide dismutase, catalase and activity of cytochrome c oxidase following arsenic exposure 
were protected in mice co-treated with arsenic and amla. Such an immunoprotective effect of amla may attribute to its antioxidant potential to counteract free radicals and prevented from enhanced oxidative stress. The fruit extract of amla has been reported to enhance cytoprotection, decrease apoptosis and DNA fragmentation $[68,69]$. It has also been found to protect against heavy metals induced clastogenicity [70]. Chromium (VI) induced free radical generation associated with enhanced oxidative stress has been found to protected following treatment with amla [30]. Further, chromium (VI) induced apoptosis, DNA fragmentation and immunosuppressive effects on lymphocyte proliferation has been ameliorated following treatment with amla and it also restored the altered levels IL-2 and $\gamma$-IFN [30]. Decreased activity of cytochrome c oxidase, mitochondrial membrane potential and increased activity of mitochondrial caspase-3, number of cells in sub G1 peak and number of apoptotic and necrotic cells in arsenic exposed mice have also been found to be protected following simultaneous treatment with arsenic and amla in the present study.

\section{Conclusions}

In conclusion, the results of the present study clearly indicated that arsenic induced free radical generation and enhance oxidative stress leading to apoptosis in thymocytes of mice. Arsenic induced decrease mitochondrial membrane potential has been found to increased following co-treatment with arsenic and amla. Further, increased number of apoptosis, necrotic cells and DNA damage following exposure to arsenic has also been found to be decreased following co-treatment with arsenic and amla indicates the anti-apoptotic property of amla that could be due to its strong antioxidative potential. Although the results of the present study exhibit immunomodulatory effects of amla through its antioxidant properties, further studies are required to understand the detailed mechanism of immunoprotection.

\section{Competing interests}

The authors declare that they have no financial or personnel competing interests.

\section{Authors' contributions}

MS: designed the experiment; MS and SY conducted research and drafting of the manuscript; VS: acquisition of data; analysis and interpretation of data; statistical analysis; SK: review of the manuscript; analysis and interpretation of data; obtained funding; administrative support; study supervision. All authors read and approved the final manuscript.

\section{Acknowledgement}

The authors thank to Head, Department of Pharmacology, King George Medical University, Lucknow for his interest in the study. The authors are also thankful to Dr. P.C. Choudhury, Professor, Government Ayurvedic College and Hospital, Lucknow. Manish Kumar Singh is grateful to the Indian Council of Medical Research, New Delhi for the award of research fellowship. The technical support by Mr. Veerendra Kumar Saini is also acknowledged.
Received: 6 March 2013 Accepted: 25 July 2013

Published: 27 July 2013

\section{References}

1. Das AK, Bag S, Sahu R, Dua TK, Sinha MK, Gangopadhyay M, et al: Protective effect of Corchorus olitorius leaves on sodium arsenite-induced toxicity in experimental rats. Food Chem Toxicol 2010, 48:326-335.

2. Flora SJS: Arsenic-induced oxidative stress and its reversibility. Free Rad Biol Med 2011, 51:257-281.

3. Chaineau E, Binet S, Pol D, Chatellier G, Meininger V: Embryotoxic effects of sodium arsenite and sodium arsenate on mouse embryos in culture. Teratology 1990, 41:105-112.

4. Chiou HY, Huang WI, Su C, Chang SF, Hsu YH, Chen CJ: Dose response relationship between prevalence of cerebrovascular disease and ingested inorganic arsenic. Stroke 1997, 28:1717-1723.

5. Rodriguez VM, Carrizales L, Jimenez-Capdeville MF, Dufour L, Giordano M: The effects of sodium arsenite exposure on behavioral parameters in the rat. Brain Res Bull 2001, 55:301-308.

6. WHO: Arsenic and arsenic compounds. Inter-organization programme for the sound management of chemicals. $2^{\text {nd }}$ ed. Environmental health criteria 224 Geneva: World Health Organization; 2001.

7. Del Razo LM, Garcia-Vargas GG, Garcia-Salcedo J, Sanmiguel MF, Rivera M, Hernandez MC, Cebrian ME: Arsenic levels in cooked food and assessment of adult dietary intake of arsenic in the Region Lagunera, Mexico. Food Chem Toxicol 2002, 40:1423-1431.

8. Rahman M: Arsenic and contamination of drinking water in Bangladesh: a public health perspective. J Health Popul Nutr 2002, 20:193-197.

9. Kapaj S, Peterson H, Liber K, Bhattacharya P: Human health effects from chronic arsenic poisoning - a review. J. Environ. Sci Health 2006, 41:2399-2428.

10. Andrew AS, Jewell DA, Mason RA, Whitfield ML, Moore JH, Karagas MR: Drinking-water arsenic exposure modulates gene expression in human lymphocytes from a U.S. population. Environ Health Perspect 2008, 116:524-531.

11. Bolt AM, Byrd RM, Klimecki WT: Autophagy is the predominant process induced by arsenite in human lymphoblastoid cell lines. Toxicol Appl Pharmacol 2010, 244:366-373

12. Bolt AM, Douglas RM, Klimecki WT: Arsenite exposure in human lymphoblastoid cell lines induces autophagy and coordinated induction of lysosomal genes. Toxicol Lett 2010, 30:153-159.

13. Banerjee N, Nandy S, Kearns JK, Bandyopadhyay AK, Das JK, Majumdez P, Basu S, Banerjee S, Sau TJ, States JC, Giri AK: Polymorphisms in the TNF-and alpha; and IL10-gene promoters and risk of arsenic-induced skin lesions and other non-dermatological health effects. Toxicol Sci 2011, Feb 25 [Epub ahead of print].

14. Raqib R, Ahmed S, Sultana R, Wagatsuma Y, Mondal D, Hoque AM, Nermell B, Yunus M, Roy S, Persson LA, Arifeen SE, Moore S, Vahter M: Effects of in utero arsenic exposure on child immunity and morbidity in rural Bangladesh. Toxicol Lett 2009, 185:197-202.

15. Moore SE, Prentice AM, Wagatsuma Y, Fulford AJ, Collinson AC, Raqib R, Vahter M, Persson LA, Arifeen SE: Early-life nutritional and environmental determinants of thymic size in infants born in rural Bangladesh. Acta Paediatr 2009, 98:1168-1175.

16. Escobar J, Varela-Nallar L, Coddou C, Nelson P, Maisey K, Valdes D, Aspee A Espinosa V, Rozas C, Montoya M, Mandiola C, Rodríguez FE, Acuna-Castillo C, Escobar A, Fernández R, Diaz H, Sandoval M, Imarai M, Rios M: Oxidative damage in lymphocytes of copper smelter workers correlated to higher levels of excreted arsenic. Mediators Inflamm 2010, 2010:403830.

17. Ahmed S, Mahabbat-e Khoda S, Rekha RS, Gardner RM, Ameer SS, Moore S, Ekstrom EC, Vahter M, Ragib R: Arsenic-associated oxidative stress, inflammation, and immune disruption in human placenta and cord blood. Environ Health Perspect 2011, 119:258-264.

18. Rahman M, Axelson O: Diabetes-mellitus and aqrsenic exposer-a second look at case controldata from a Swedish copper smelter. Occup Environ Med 1995, 52:773-774.

19. Kitchin KT: Recent advances in arsenic carcinogenesis: modes of action, animals model system, and methylated arsenic metabolites. Toxicol Appl Pharmacol 2001, 172:249-261.

20. Stepnik M, Stanczyk M, Arkusz J, Lewinska D: Assessment of apoptosis in thymocytes and splenocytes from mice exposed to arsenate in drinking water: cytotoxic effects of arsenate on the cells in vitro. J Environ Sci Health A Tox Hazard Subst Environ Eng 2005, 40:369-84. 
21. Sharma A, Sharma MK, Kumar M: Modulatory role of Emblica officinalis fruit extract against arsenic induced oxidative stress in swiss albino mice. Chemico-Biol Interaction 2009, 180:20-30

22. Schaumloffel N, Gebel T: Heterogeneity of the DNA damage provoked by antimony and arsenic. Mutagenesis 1998, 13:281-286.

23. Mukherjee S, Roy M, Dey S, Bhattacharya RK: A mechanistic approach for modulation of arsenic toxicity in human lymphocytes by curcumin, an active constituent of medicinal herb Curcuma longa Linn. J. Clin. Biochem. Nutr 2007, 41:32-42.

24. Ramirez P, Del Razo LM, Gutierrez-Ruiz MC, Gonsebatt ME: Arsenite induces DNA-protein crosslinks and cytokeratin expression in the WRL-68 human hepatic cell line. Carcinogenesis 2000, 21:701-706.

25. Li D, Morimoto K, Takeshita T, Lu Y: Formamidopyrimidine- DNA glycosylase enhances arsenic-induced DNA strand breaks in PHA-stimulated and unstimulated human lymphocytes. Environ Health Perspect 2001, 109:523-526.

26. Abernathy CO, Liu YP, Longfellow D, Aposhian HV, Fowler B, Goyer R, Menzer R, Rossman T, Thompson C, Walkes M: Arsenic: health effects, mechanisms of actions and research issues. Environ Health Perspect 1999, 107:593-597.

27. Basu A, Mahata J, Gupta S, Giri AK: Genetic toxicology of a paradoxical human carcinogen, arsenic: a review. Mutat Res 2001, 488:171-194.

28. Yadav RS, Sankhwar ML, Shukla RK, Chandra R, Pant AB, Islam F, Khanna VK: Attenuation of arsenic neurotoxicity by curcumin in rats. Toxicol Appl Pharmacol 2009, 240:367-376.

29. Yadav RS, Sankhwar ML, Shukla RK, Chandravanshi LP, Ansari RW, Shukla PK, Pant AB, Khanna VK: Neuroprotective efficacy of curcumin in arsenic induced cholinergic dysfunctions in rats. Neurotoxicology 2011, 32:760-768.

30. Sai Ram M, Neetu D, Yogesh B, Anju B, Dipti P, Pauline T, Sharma SK, Sarada SK llavazhagan G, Kumar D, Selvamurthy W: Cyto-protectiveand immunomodulating properties of Amla (Emblica officinalis) on lymphocytes: an in-vitro study. J Ethnopharmacol 2002, 81:5-10.

31. Khandelwal S, Shukla LJ, Shanker R: Modulation of acute Cadmium toxicity by by Emblica officinalis fruit in rat. Exp Bio 2002, 40:564-570.

32. Poltanov EA, Shikov AN, Dorman HJD, Pozharitskaya ON, Makarov VG, Tikhonov VP, et al: Chemical and antioxidant evaluation of Indian gooseberry (Emblica officinalis Gaertn., syn. Phyllanthus emblica L.) supplements. J Phytotherapy Res 2009, 23:1309-1315.

33. Sreeramulu D, Raghunath M: Antioxidant activity and phenolic content of roots, tubers and vegetables commonly consumed in India. Food Res Int 2009, 43:1017-1020

34. Adams LS, Seeram NP, Aggarwal BB, Takada YS, Heber D: Pomegranate juice, total pomegranate ellagitannins, and punicalagin suppress inflammatory cell signaling in colon cancer cells. J Agri Food Chem 2006, 54:980-985.

35. Institoris L, Siroki O, Undeger U, Basaran N, Desi I: Immunotoxicological investigation in rats dosed repeatedly with combinations of cypermethrin, As (III), and Hg(II). Toxicology 2002, 172:59-67.

36. El-Demerdash FM, Yousef MI, Radwan FM: Ameliorating effect of curcumin on sodium arsenite-induced oxidative damage and lipid peroxidation in different rat organs. Food Chem Toxicol 2009, 47:249-254.

37. Liu X, Cui C, Zhao M, et al: Identification of phenolics in the fruit of emblica (Phyllanthus emblica L.) and their antioxidant activities. Food Chem 2008, 109:909-915.

38. Luo W, Zhao M, Yang B, Shen G, Rao G: Idntification of bioactive compounds in Phllenthus emblica L. fruit and their free radical scavenging activities. Food Chem 2009, 114:499-504.

39. Yang B, Zhao MM, Prasad KN, Jiang GX, Jiang YM: Effect of methylation on the structure and radical scavenging activity of polysaccharides from longan (Dimocarpus longan Lour.) fruit pericarp. Food Chem 2010, 118:364-368.

40. Mosmann T: Rapid colorimetric assay for cellular growth and survival: application to proliferation and cytotoxicity assays. J Immunol Methods 1988, 65:55-63.

41. Ohkawa H, Osishi N, Yagi K: Assay for lipid peroxide in animal tissue by thiobarbituric acid reaction. Anal Biochem 1979, 251:351-358.

42. Moron MS, Depierre JW, Mannervik B: Levels of glutathione, glutathione reductase and glutathione S-transferase activities in rat lung and liver. Biochim Biophys Acta 1979, 582:67-78.

43. Marklund S, Marklund G: Involvement of superoxide anion radical in auto oxidation of pyrogallol and a convenient assay for superoxide dismutase. Eur J Biochem 1974, 47:469-474.
44. Aebi H: Catalase in vitro. In Methods in Enzymology, Academic Press, New York, Volume 105. Edited by Packer L. ; 1984:121-126.

45. Pathak N, Khandelwal S: Immunomodulatory role of piperine in cadmium induced thymic atrophy and spleenomegaly in mice. Environ Toxicol Pharmacol 2009, 28:52-60.

46. Paglia DE, Valentine WM: Studies on the qualitative and quantitative characterization of erythrocyte glutathione peroxidase. J Lab Clin Med 1967, 70:158-169.

47. Bai J, Rodriquez AM, Melendez JA, Cederbaum Al: Over expression of catalase in Cytosolic or mitochondrial compartment protects HepG2 cells against oxidative injury. J Biochem 1999, 274:26217-24.

48. Darzynkiewicz Z, Juan G, Li X, Gorczca W, Murakami T, Traganos F: Cytometry in cells necrobiology: analysis of apoptosis and accidental cell death (necrosis). Cytometry 1997, 27:1-20.

49. Vermes I, Haanen C, Steffens-Nakken H, Recutelings-Perger C: Anovel assay for apoptosis, flow cytometric detetion of phosphatidy/serine expression on early apoptotic cells using fluorescein-labeled Annexin V. J Immunol method 1995, 184:39-44.

50. Lowry OH, Rosebrough NJ, Farr AL, Randall RJ: Protein measurement with the Folin phenol reagent. J Biol Chem 1951, 193:263-275.

51. Gupta R, Flora SJ: Effect of Centella asiatica on arsenic induced oxidative stress and metal distribution in rats. J Applied Toxicol 2006, 26:213-222.

52. Banerjee N, Banerjee M, Ganguly S, Bandyopadhyay S, Das JK, Bandyopadhay A, Chatterjee M, Giri AK: Arsenic-induced mitochondrial instability leading to programmed cell death in the exposed individuals. Toxicology 2008, 246:101-111.

53. Majumdar S, Karmakar S, Maiti A, Choudhury M, Ghosh A, Das AS, Mitra C: Arsenic-induced hepatic mitochondrial toxicity in rats and its amelioration by dietary phosphate. Environ Toxicol Pharmacol 2011, 31:107-118.

54. Maeda H, Hori S, Nishitoh H, Ichijo H, Ogawa O, Kakehi Y, Kakizuka A: Tumor growth inhibition by arsenic trioxide (As2O3) in the orthotopic metastasis model of androgen-independent prostate cancer. Cancer Res 2001, 61:5432-5440.

55. Hossain K, Akhand AA, Kato M, Du J, Takeda K, Wu J, Takeuchi K, Liu W, Suzuki $H$, Nakashima I: Arsenite induces apoptosis of murine T lymphocytes through membrane raft-linked signaling for activation of c-Jun amino-terminal kinase. J Immunol 2000, 165:4290-4297.

56. Martin-Chouly C, Morzadec C, Bonvalet M, Galibert MD, Fardel O, Vernhet $L$ : Inorganic arsenic alters expression of immune and stress response genes in activated primary human T lymphocytes. Mol Immunol 2011, 48:956-965.

57. Bustamante J, Dock L, Vahter M, Fowler B, Orrenius S: The semiconductor elements arsenic and indium induce apoptosis in rat thymocytes. Toxicology 1997, 118:129-136.

58. Flora SJS, Bhatt K, Mehta A: Arsenic moiety in gallium arsenide is responsible for neurona apoptosis and behavioral alterations in rats. Toxicol Appl Pharmacol 2009, 240:236-244.

59. Schulz H, Nagymajtényi L, Institoris L, Papp A, Siroki O: A study on behavioral, neurotoxicological, and immunotoxicological effects of sub-chronic arsenic treatment in rats. J Toxicol Environ Health A 2002, 65:1181-1193.

60. Karim MR, Haque A, Islam K, Ali N, Salam KA, Saud ZA, Hossain E, Fajol A, Akhand AA, Himeno S, Hossain K: Protective effects of the dietary supplementation of turmeric (Curcuma longa L.) on sodium arseniteinduced biochemical perturbation in mice. Bangladesh Med Res Counc Bull 2010, 36:82-88.

61. Ferreira M, Matos RC, Oliveira H, Nunes B, Pereira MD: Impairment of mice spermatogenesis by sodium arsenite. Hum Exp Toxicol 2011, Apr 13 [Epub ahead of print].

62. Yildirim A, Oktay M, Bulaloulu V: The antioxidant activity of the leaves of Cydonia vulgaris. Turkish J Med Sci 2001, 31:23-27.

63. Dash DK, Yeligar VC, Nayak SS, Ghosh T, Rajalingam D, Sengupta P, Maiti BC, Maity T: Evaluation of hepatoprotective and antioxidant activity of Ichnocarpus frutescens (Linn.) R.Br. on paracetamol-induced hepatotoxicity in rats. Trop J Pharmaceu Res 2007, 6:755-765.

64. Reddy VD, Padmavathi P, Paramahamsa M, Varadacharyulu NC: Amelioration of alcohol-induced oxidative stress by Emblica officinalis (amla) in rats. Indian J Biochem Biophys 2010, 47:20-25.

65. Kumar MR, Reddy AG, Anjaneyulu Y, Reddy GD: Oxidative stress induced by lead and antioxidant potential of certain adaptogens in poultry. Toxicol Int 2010, 17:45-48. 
66. Haque R, Bin-Hafeez B, Ahmad I, Parvez S, Pandey S, Raisuddin S: Protective effects of Emblica officinalis Gaertn in cyclophosphamide-treated mice. Hum Exp Toxicol 2001, 20:643-650.

67. Srikumar R, Parthasarathy NJ, Manikandan S, Narayanan GS, Sheeladevi R: Effect of Triphala on oxidative stress and on cell-mediated immune response against noise stress in rats. Mol Cell Biochem 1996, 283:67-74.

68. Bhattacharya A, Chatterjee A, Ghosal S, Bhattacharya SK: Antioxidant activity of active tannoid principle of Emblica officinalis (Amla). Indian J Exp Biol 1999, 37:676-680.

69. Bandyopadhyay SK, Pakrashi SC, Pakrashi A: The role of antioxidant activity of Phyllanthus emblica fruits on prevention from indomethacin induced gastric ulcer. J Ethnopharmacol 2000, 70:171-176.

70. Roy AK, Dhir H, Sharma A: Modification of metal-induced micronuclei formation in mouse bone marrow erythrocytes by Phyllanthus fruit extract and ascorbic acid. Toxicol Lett 1992, 62:9-17.

doi:10.1186/1472-6882-13-193

Cite this article as: Singh et al.: Immunomodulatory role of Emblica officinalis in arsenic induced oxidative damage and apoptosis in thymocytes of mice. BMC Complementary and Alternative Medicine 2013 13:193.

\section{Submit your next manuscript to BioMed Central and take full advantage of:}

- Convenient online submission

- Thorough peer review

- No space constraints or color figure charges

- Immediate publication on acceptance

- Inclusion in PubMed, CAS, Scopus and Google Scholar

- Research which is freely available for redistribution 